\title{
Grāmatas ar pilnīgas slepenības zīmogiem - aukstā kara liecības Latvijas bibliotēkās
}

Atslēgvārdi: padomju okupācija Latvijā, aukstais karš, latviešu trimdas literatūra, pilnīgas slepenības zīmogi, bibliotēku specfondi.

\section{levads}

Pēc Otrā pasaules kara atkārtoti okupētā Latvija tika iesaistīta ilgstošā ASV un PSRS, kā arī to sabiedroto valstu konfrontācijā, kas ietekmēja visas dzīves jomas. Bibliotēku nozarē tā izpaudās tiešā un netiešā cenzūrā, tajā skaitā krājumu komplektēšanas un aprites ierobežojumos. Gandrīz katrs no Padomju Savienībai "nedraudzīgajām" kapitālistiskajām valstīm ienākošais iespieddarbs tika pārbaudīts vispirms uz PSRS robežas muitas vai pasta kontroles punktos, pēc tam bibliotēkās, kurām bija tiesības šo ārzemju literatūru saṇemt (šādu organizāciju skaits bija ierobežots). Lielākā daḷa latviešu trimdas ${ }^{1}$ izdevumu, kas bija iznākuši kapitālistiskajās valstīs, piemēram, ASV,

1 Padomju okupācijas varas dokumentos tika lietots apzīmējums "latviešu emigrantu jeb emigrācijas literatūra", savukārt jēdziens "trimda" izmantots latviešu diasporas publikācijās un Latvijā ieviesies t. s. trešās atmodas laikā, uzsverot konkrētas personas vai personu grupas piederību politiskajiem bēg̣̣iem, kas devās prom no dzimtenes uz Rietumvalstīm, lai izvairītos no komunistiskā režīma represijām. Tā kā jēdziens "trimdas literatūra" ir aprobēts latviešu akadēmiskajās publikācijās, tas izmantots arī šajā rakstā, apzīmējot politisko bēgḷu izdoto literatūru latviešu diasporas zemēs.
Kanādā, Vācijas Federatīvajā Republikā, Lielbritānijā un citās latviešu mītnes zemēs, tika klasificēta kā izteikta pretpadomju literatūra, kas ieguva pilnīgas slepenības statusu un tika apzīmogota ar diviem sešstūriem. Pat aizliegtās literatūras nodaḷās jeb specfondos tā bija jāinventarizē un jākatalog̣izē, jāglabā atsevišḳi no pārējā krājuma - dzelzs seifos, tās izmantošanai bija iekārtojama īpaša lasītava un bija nepieciešama ne tikai bibliotēkas direktora, bet arī Latvijas Komunistiskās partijas (LKP) Centrālās komitejas (CK) atḷauja.

Britu ekonomikas profesors Marks Harisons norāda, ka Padomju Savienībā valdošās vienīgās - Komunistiskās - partijas (PSKP) noteicošais darbības princips bija slepenība, kas tika nostiprināta pat vairākos PSKP CK politbiroja lēmumos 20. gados. ${ }^{2}$ Tas nozīmēja, ka "[..] slepeni materiāli izpaužami tikai tiem, kuriem ir absolūta nepieciešamība būt informētiem". ${ }^{3}$ Slepenības režìms pastāvēja katrā lielākā padomju organizācijā, kur darbam ar slepeno informāciju bija izveidota īpaša (pirmā) nodaḷa. Parasti to vadīja PSKP biedri, uzraudzīja Valsts drošības komiteja (VDK). ${ }^{4}$ "No sākuma līdz beigām,"

2 Harrison, M. 2013. Accounting for Secrets. The Journal of Economic History, 73 (4), p. 1019. Pieejams: www.jstor.org/stable/24551010 [skatīts 21.11.2019.].

3 Turpat.

4 Sk.: Grybkauskas, S. 2007. The Soviet dopusk System as Society Control Lever in the Industry of Soviet Lithuania during 1965-1985. No: Latvija un Austrumeiropa 20. gadsimta 60.-80. gados: 
uzsver M. Harisons, Padomju Savienības "[..] stabilitāte balstījās uz spēju monopolizēt un pārvaldīt informāciju. Kad beidzās slepenība, beidzās arī komunisma vara." ${ }^{5}$ Cenzori bija pēdējais posms daudzu filtru virknē, kas bija izveidota, lai nepiel̦autu slepenas informācijas nokḷūšanu publiskā telpā.

Slepenības režīmam bija vairākas pakāpes. 80. gados sovetologs Reimonds Hačingss (Raymond Hutchings), kurš pētījis ierobežotas pieejamības informāciju Padomju Savienībā vēl pirms tās sabrukuma, konstatējis trīs pamatpakāpes: "nav izpaužams" (не подлежит оглашению), "slepeni" (секретно), "stingri slepeni” (строго секретно). ${ }^{6}$ Lietuviešu vēsturnieks S. Grībkausks līdztekus kategorijai "slepeni" fiksējis vēl divas: "sevišksi svarīgi” (особоŭ важности), "pilnīgi slepeni" (совершенно секретно) 7 . Krievu juriste G. Kamanova ierobežotas pieejamības informāciju klasificē trīs galvenās grupās: "valsts noslēpums" ("sevišk, svarīgi”, "pilnīgi slepeni”), "dienesta noslēpums" ("slepeni") un "dienesta vajadzībām". ${ }^{8}$ Slepenās informācijas daudzpakāpju sistēma apstiprina M. Harisona tēzi par slepenību kā svarīgāko Padomju Savienības stabilitātes

starptautiskās konferences referāti. 2006. gada 10. oktobris, Riga = Latvia and Eastern Europe in the 1960s-1980s: materials of international conference 10 October 2006. Rīga: Latvijas Vēsturnieku komisija, Latvijas Universitātes Latvijas vēstures inst., Latvijas Kara muzejs, 79.-86. lpp.

5 Harrison, M. 2013. Accounting for Secrets, p. 1020.

6 Hutchings, R. 1987. Soviet Secrecy and Non-secrecy. Totowa, New Jersey: Barnes \& Noble books, p. 20.

7 Grybkauskas, S. 2007. The Soviet dopusk System as Society Control Lever in the Industry of Soviet Lithuania during 1965-1985, p. 80.

8 Камалова, Г. 2014. Исторические особенности правовой охраны служебной информации ограниченного доступа (служебной тайны) в советский период. Вестник Удмуртского университета. Серия “Экономика и право”. Pieejams: https://cyberleninka.ru/article/n/ istoricheskie-osobennosti-pravovoy-ohranysluzhebnoy-informatsii-ogranichennogo-dostupasluzhebnoy-tayny-v-sovetskiy-period [skatīts 21.11.2019.]. balstu un liek domāt par ārkārtīgi ierobežoto informācijas telpu, ko padomju vara atvēlēja sabiedrības zemākajam slānim, pie kura, kā norāda S. Grībkausks, tika pieskaitīti politiski "neuzticamie elementi". 9 "Valsts noslēpumu" bija l̦auts zināt vienīgi vadošajam personālam, kura lojalitāte varai nebija apšaubāma. ${ }^{10}$ Publicējamās informācijas, kā arī no ārzemēm ienākošo izdevumu kontroli vadīja PSRS Ministru padomes (MP) Galvenā pārvalde valsts noslēpumu aizsardzībai presē (Главное управление по охране государственных тайн в печати nрu CM CCCP), kurai bija padota atbilstoša institūcija arī Latvijā - LPSR MP Galvenā pārvalde valsts noslēpumu aizsardzībai presē (turpmāk LPSR GLP). "Valsts noslēpuma" un daudzos gadījumos arī "dienesta noslēpuma" izpaušana "nepiederošām" personām (tām, kurām nebija tiesību zināt) bija krimināli sodāms pārkāpums. ${ }^{11}$

Ar diviem sešstūriem apzīmogotā literatūra bija pilnīgi slepena, tātad pielīdzināta "valsts noslēpumam". To drīkstēja san,emt tikai tās organizācijas un personas, kurām "darbības rakstura dēl tā ir absolūti nepieciešama" (строго необходимо по роду их деятельности). ${ }^{12}$ Pilnīgi slepeni bija "[..] ārzemju izdevumi - buržuāziskie, trockistu, emigrantu, revizionistu - kuros publicēti izteikti naidīgi, pretpadomju un antikomunistiski materiāli, launprātīgi un provocējoši izlēcieni pret PSKP

9 Grybkauskas, S. 2007. The Soviet dopusk System as Society Control Lever in the Industry of Soviet Lithuania during 1965-1985, p. 81-82.

10 Turpat.

11 Izvilkumi no Latvijas Padomju Sociālistiskās Republikas kriminālkodeksa. No: Vīksne, R., Kangeris, K. (red.) 1999. No NKVD lidz KGB: politiskās prāvas Latvijā 1940-1986. Rīga: Latvijas vēstures institūta apgāds, 964. lpp.

12 Главное управление по охране государственных тайн в печати при СМ ЛССР (Главлит ЛССР). Порядок учета, хранения и использования иностранных изданий, отмеченных Главным управлениям двумя знаками "шестигранных" и пропускаемых в организации для особого использования. LVA, 917. f., 1.a apr., 113. 1., 3. lp. 
vadītājiem un padomju valdību un citi materiāli ar ideoloğiskas un politiskas diversijas raksturu". ${ }^{13}$ Lìdz 1987. gadam it visi emigrantu organizāciju izdevumi bija glabājami specfondos, arī tad, ja neietvēra pretpadomju informāciju. ${ }^{14}$

Pilnīgi slepenās, ar diviem sešstūriem apzīmogotās trimdas literatūras cirkulācija okupētajā Latvijā līdz šim ir maz pētīta. Bibliotēku vēsturniece Aina Štrāle savos rakstos "Sešstūru zīmogs"15 un "Kā LPSR cenzūra gatavojās sadedzināt Bībeli"16 raksturojusi Latvijas PSR cenzūras galvenās institūcijas - GLP jeb Glavḷita - aktivitātes trimdas sūtījumu vētīšanā un iznīcināšanā, atseviški neizceḷot tās darbu ar pilnīgi slepenajiem iespieddarbiem. Arī vēsturnieks Heinrihs Strods (1925-2012) vairākās apjomīgās publikācijās pievērsies trimdas literatūras cenzūrai okupētajā Latvijā, pilnīgi slepenajiem izdevumiem atvēlot vien dažas rindas. ${ }^{17}$ To nosaka abu vēsturnieku izvēlētā galvenā avotbāze - LPSR GLP fonds

13 Главное управление по охране государственных тайн в печати при СМ ЛССР (Главлит ЛССР). Порядок учета, хранения и использования иностранных изданий, отмеченных Главным управлениям двумя знаками "шестигранных" и пропускаемых в организации для особого использования. LVA, 917. f., 1.a apr., 113. 1., 3. lp.

14 Отчет о работе Главлита ЛССР за 1987 год. LVA, 917. f., 1.a apr., 212. 1., 8. 1p.

15 Štrāle, A. 2005. Sešstūru zīmogs: no LPSR cenzūras sākotnes līdz funkciju izsīkumam. Daži aspekti. Diena, Nr. 182. Pieejams: http://news. lv/Diena/2005/08/06/sessturu-zimogs [skatīts 21.11.2019.].

16 Štrāle, A. 2005. Kā LPSR cenzūra gatavojās sadedzināt Bībeli: [par LPSR Ministru Padomes Galv. pārvaldes valsts noslēpumu aizsardzībai presē darbību]. Karogs, Nr. 8, 133.-138. lpp.

17 Strods, H. 2007. Trimdas izdevumu cenzūra Latvijas PSR 1958.-1989. gadā. No: Latvijas Vēsturnieku komisija, Latvijas Universitātes Latvijas Vēstures institūts. Latvijas kara muzejs. Latvija un Austrumeiropa 20. gadsimta 60.-80. gados: starptautiskās konferences referāti. 2006. gada 10. oktobris, Riga = Latvia and Eastern Europe in the 1960s-1980s: Materials of international conference 10 October 2006, Riga. Rīga: Latvijas vēstures institūta apgāds, 88.-95. lpp.;
LNA, kurā datu par pilnīgi slepeno literatūru ir salīdzinoši maz. Informāciju par LPSR Zinātṇu akadēmijas Fundamentālās bibliotēkas (ZA FB, mūsdienās Latvijas Universitātes Akadēmiskā bibliotēka) Literatūras speciālās glabāšanas nodalıu jeb specfondu, kurā bija uzkrāti un lasāmi "visreakcionārākie" emigrācijas izdevumi ar diviem sešstūra zīmogiem, sniedz bibliotēku speciālistes Janas Klebās maǵistra darbs. ${ }^{18}$ Tā izstrādē izmantoti arī Latvijas Universitātes Akadēmiskās bibliotēkas (LU AB) dokumenti, bibliotekāru un kādreizējā specfonda lasītāju - rakstnieku, zinātnieku - atmiņas. Tomēr J. Klebās pētījuma objekts ir ZA FB specfonda darbība kopumā, tādēḷ pilnīgi slepenās emigrācijas literatūras komplektēšana un izmantošana tajā nav detalizēti aplūkota.

Šì pētījuma nolūks ir izvērtēt emigrācijā izdotās pretpadomju literatūras iegūšanas, saglabāšanas un pieejamības politiku okupētajā Latvijā aukstā kara gados un noteikt, kādu lomu padomju vara tai bija paredzējusi ideoloǵiskajā karā pret ASV. Pētījumā izmantoti galvenokārt to bibliotēku dokumenti, kurām padomju okupācijas vara oficiāli aț̣āva saṇemt un glabāt šo literatūru, tas ir, ZA FB, LPSR Valsts bibliotēkai (VB, mūsdienās Latvijas Nacionālā bibliotēka) un LKP CK partijas vēstures institūta (LKP CK PVI) - PSKP CK Marksisma-l̦eninisma institūta filiāles - bibliotēkai. Tās krājums pēc valsts neatkarības atjaunošanas integrēts Latvijas Nacionālā arhīva bibliotēkā.

Strods, H. 2010. Ārzemju un trimdas literatūras cenzūra. No: Strods, H. PSRS politiskā cenzūra Latvijā 1940-1990. 1. d. Rīga: Jumava, 360.-400. lpp.

18 Klebā, J. 2007. Okupācijas varas cenzūras darbība Latvijas Akadēmiskajā bibliotēkā. Maǵistra darbs. Rīga: LU. 


\section{Latviešu emigrācijas iespieddarbu aprite okupācijas pirmajās desmitgadēs}

Okupācijas pirmajā desmitgadē Latvijas bibliotēkas tikpat kā nesaṇēma informāciju no ASV un citām kapitālistiskajām valstīm. Vienīgi ZA FB jau 1948. gadā bija atḷauta literatūras iegāde no šīm valstīm, ieskaitot ASV, Lielbritāniju, Kanādu, turklāt no ASV tika saṇemts lielākais žurnālu nosaukumu daudzums. ${ }^{19}$ 1949. gada nogalē tā atsāka arī grāmatu apmaiņu ar ārzemju institūcijām. Citu bibliotēku sakari ar kapitālistiskajām valstīm kḷuva iespējami tikai pēc režīma liberalizēšanās 50 . gadu otrajā pusē. Piemēram, VB grāmatu apmaiṇu ar kapitālistiskajām valstīm uzsāka tikai 1959. gadā. ${ }^{20}$ Pamazām latviešu emigrācijas izdevumi ienāca ZA FB, VB, LKP CK PVI bibliotēkā, kā arī vairākās citās LPSR iestādēs. ${ }^{21}$

19 Katajs, E. 1973. Ārzemju literatūra bibliotēkas fondos. No: Bibliotēka - zinātnei. Rīga: Zinātne, 64.-65. lpp.

20 1958. gada 10. aprīlī PSRS MP izdeva rīkojumu, kas republikāniskajām bibliotēkām (to skaitā arī VB) deva tiesības tieši apmainīties ar literatūru ar ārvalstu organizācijām. Viška, J. 1973. Lāča Latvijas PSR Valsts bibliotēkas fondu komplektēšana (1945-1970). No: V. Lāča Latvijas PSR Valsts bibliotēka. Raksti $=$ Tpydbı $=$ Proceedings IV, 146. 1pp.

21 Iespējams, ka slēgtajās, l,oti ierobežotam personu lokam pieejamās iestāžu bibliotēkās latviešu trimdas literatūra tikusi komplektēta jau Stalina laikā. Spriežot pēc "reakcionārās" emigrantu preses analītiskajiem pārskatiem, kas regulāri iesūtīti LKP CK, šāds krājums bijis LPSR Ārlietu ministrijā, kā arī LPSR Valsts drošības komitejā, kas sistemātiski saṇēma daḷu pastā konfiscēto izdevumu. Sk.: Latvijas PSR Valsts drošības komitejas zinātniskās izpētes komisija. Pārskats par periodu no 2017. gada 1. janvāra lìdz 2018. gada 31. maijam. Rīga, 2018. Pieejams: https://lvportals.lv/wwwraksti/ LVPORTALS/VDKPARSKATS.PDF [skatīts 21.11.2019.].
Ar PSRS MP lēmumu 1948. gada 25. oktobrī visi Latvijas iestādēm paredzētie ārzemju literatūras sūtījumi tika kontrolēti Maskavā, PSRS GLP cenzūras punktā. Lielākā daḷa tajā ienākošo latviešu izdevumu tika iznīcināta kā pretpadomju informācija. ${ }^{22}$ N̦emot vērā straujo sūtījumu palielināšanos, 1958. gada augustā PSRS GLP uzdeva ārzemju latviešu literatūras bandroḷu pārskatīšanu LPSR GLP, jo tā labāk pārzina vietējos apstākḷus un sūtījumu adresātus. ${ }^{23}$ LPSR GLP cenzūras punkts darbu uzsāka 1958. gada novembrī un jau pirmajos divos darbības mēnešos izskatīja vairāk nekā 500 bandroḷu ${ }^{24}$ Gandrīz visi sūtījumi tika aizturēti, adresātus sasniedza vien neliela daļa (16\%).

Brīva latviešu emigrācijas iespieddarbu komplektēšana ZA FB un VB specfondiem nebija atḷauta, tomēr pakāpeniski veidojās lielāki preses un grāmatu uzkrājumi. Piemēram, VB saņēma laikrakstu "Labietis", rakstu krājumu “Jaunā Gaita" 1, žurnālus "Tilts", "Mazputniņš", izteikti kreiso mēnešrakstu "Viesis" 25 un

22 Главлит СССР. Секретарю ЦК Компартии Латвии тов. Калнберзину Я. Я. 31.07.1958. LVA, PA-101. f., 21. apr., 77. 1., 11.-12. 1p.

23 Turpat, 12. lp.

24 Главлит ЛССР. Справка о работе цензорского пункта Главлита Латвийской ССР при почтамте гор. Риги за 1958 год. LVA, PA-101. f., 22. apr., 83. 1., 7. 1p.

25 Mēnešrakstu Austrālijā, Adelaidē, izdeva literāts, pedagogs Vilis Ešots (1907-1979). Pēc Ulda Siliṇa atmiņām, 50. gadu otrajā pusē viņš "pavisam atklāti pāriet komunistu pusē". Sk.: Siliņš, U. 2015. Zem Dienvidu Krusta (1950-1992). Atminu trilogijas noslēdzošā daḷa. Pieejams: https://www.historia. lv/sites/default/files/media/Biblioteka/Literatura/ Gramatas/2015/ZDK/zdk_kopsavilkums_060815. pdf [skatīts 21.11.2019.]. Kādreizējā LPSR VDK līdzstrādnieka un Latvijas Komitejas kultūras sakariem ar tautiešiem ārzemēs vadītāja I. Lešinska (1931-1985) atmin̄ās šo "progresīvo" žurnālu finansēja LPSR VDK. Sk.: Lešinskis, I. 1986. Kultūras sakari vai etniskā spiegošana: to kādreizējā veidotāja viedoklis. Latvija Šodien, Nr. 14, 1. dec., 109.-118. lpp. 
citus turpinājumizdevumus ${ }^{26}$, kā arī grāmatas. Daļa izdevumu Latvijā ienāca masveidā, bez saskan,ošanas ar adresātu. Tā 1958. gadā Eduarda Dobeḷa (1915-1977) apgāds "Latvju Grāmata" (ASV) nosūtīja ZA FB 35 izdevumus. ${ }^{27}$ Šis sūtījums ienāca PSRS cenzūras punktā Maskavā, taču netika iznīcināts, bet saskaņā ar LKP CK lēmumu sasniedza bibliotēku. ${ }^{28}$ Jau 1960. gadā, kad bija pastiprinājusies ASV un tās sabiedroto informatīvā ietekme PSRS - to bija veicinājušas arī vairākas ASV Centrālās izlūkošanas pārvaldes mērk,programmas, tajā skaitā grāmatu izdošanā un izplatīšanā ${ }^{29}$-, LPSR VDK priekšsēdētājs Jānis Vēveris (1899-1978) ierosināja emigrācijas literatūru koncentrēt tikai vienā - ZA FB - specfondā. ${ }^{30}$ Tomēr līdzšinējā prakse turpinājās, acīmredzot okupētās Latvijas augstākā vara nebija ieinteresēta pārāk striktos ierobežojumos. Pārmaiņas raisīja pieaugošā spriedze Padomju Savienības inteligences un varas attiecībās ${ }^{31}$. 1957. gada novembrī Milānā "Feltrinelli" izdevniecībā iznāca krievu rakstnieka Borisa Pasternaka (1890-1960) romāns "Doktors Živago", kuru autors bija iedevis itāliešu žurnālistam Serdžo D'Andželo (Sergio D’Angelo) slepenai izvešanai un iespiešanai ārzemēs, - nebija cerību, ka tas varētu ieraudzìt

26 Отдел спецфонда Гос. библиотеки Латвийской СССР. Секретно. Инвентарная книга для журналов. 1948.-1972. г. LNB, Reto grāmatu un rokrakstu krājums, Latvijas VB specfonda nodaḷa RXA 324, Nr. 17.

27 Начальник Главлита СССР. Секретарю ЦК Компартии Латвии тов. Калнберзиню Я. Я. LVA, PA-101. f., 21. apr., 77. 1., 14. lp.

28 Turpat.

29 Vairāk sk.: Finn, P., Couvée, P. 2015. The Zhivago affair: the Kremlin, the CIA, and the battle over a forbidden book. New York: Vintage Books.

30 Председатель комитета государственной безопасности ЛССР Я. Веверис секретарю ЦК КПЛ А. Воссу о хранении латышской эмигрантской литературы 5.07.1960. LVA, PA-101. f., 23. apr., 136. 1., 135. lp.

31 Bērzinšs, U. 2013. Varbūt šoreiz? Jaunā Gaita, Nr. 274. Pieejams: https://jaunagaita.net/jg274/ JG274_Pragas-pavasaris.htm [skatīts 21.11.2019.].

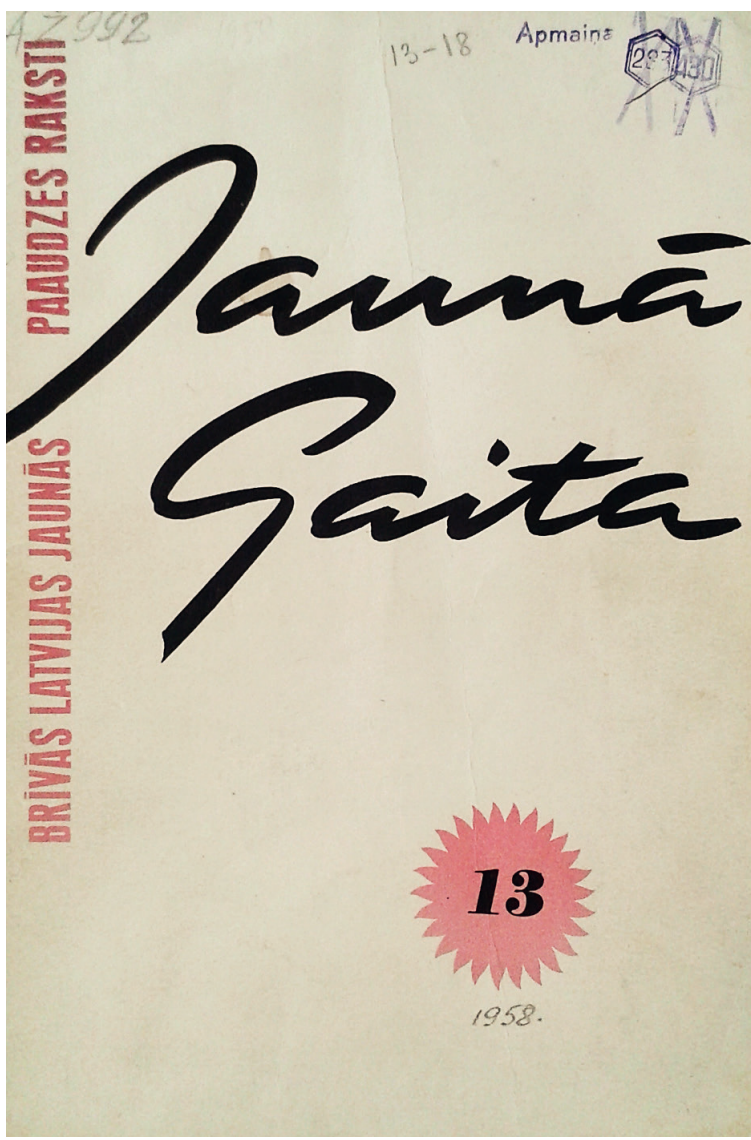

Latviešu emigrācijas turpinājumizdevumi visbīstamākā "pretpadomju" literatūra. Attēlā rakstu krājums "Jaunā Gaita", apzīmogots diviem sešstūra zīmogiem. LPSR ZA FB eksemplārs, mūsdienās atrodams LU AB 
dienasgaismu Krievijā. ${ }^{32}$ Romāns tūlīt izpelnījās ne tikai plašu lasošās publikas, bet arī ASV Centrālās izlūkošanas pārvaldes (CIP) uzmanību, jo proponēja brīvu, kontrrevolucionāru, pat apolitisku dzìves skatījumu. CIP uzdevumā tas 1958. gadā tika izdots atkārtoti slepenai izplatîšanai PSRS. Tas bija pirmais padomju autora darbs, kas tika mērķtiecīgi izmantots ASV ideoloǵiskajā karā pret PSRS. Romāns tika operatīvi tulkots arī latviešu valodā un iznāca Kopenhāgenā, trimdas apgādā "Imanta" 1959. gadā. ${ }^{33}$ Latviešu izdevuma apvākā akcentēts, ka romāns "[..] apsūdz marksismu, kritizē komūnisma revolūciju un atklāj padomju sistēmas varmācību un tās noziegšanos pret visu, kas dzīvi dara dzīvošanas vērtu". ${ }^{34}$ Tādēl B. Pasternaks smagi cieta - viņš bija spiests atteikties no Nobela prēmijas literatūrā, ko viņam par romānu piešķīra 1958. gadā, turklāt vinuu izslēdza no PSRS Rakstnieku savienības un vinam tika liegta iespēja publicēt savus orig̛ināldarbus. Drīz, 1960. gadā, viņš pēc ilgstošas, grūtas slimības aizgāja mūžībā. Neskatoties uz B. Pasternaka traǵisko likteni, viņa paraugam - publicēt cenzūras neatḷautus darbus ārpus Padomju Savienības - sekoja citi. ${ }^{35}$ Tā, piemēram, literatūrzinātnieks un rakstnieks Andrejs Siņavskis (1925-1997) savus pirmos prozas sacerējumus publicēja Parīzē 50. gadu beigās ar pseidonīmu Ābrams Tercs. ${ }^{36}$

32 Finn, P., Couvée, P. 2015. We tore a big hole in the Iron Curtain, p. 113.

33 Pasternaks, B. 1959. Doktors Živago. Kopenhāgena: Imanta, 475 lpp. Romāna fragmenti Pāvila Klāna tulkojumā publicēti jau 1958. gadā laikrakstā "Laiks".

34 Turpat.

35 Kind-Kovács, F. 2014. Written Here, Published There : How Underground Literature Crossed the Iron Curtain. Budapest: Central European University Press, p. 45.

36 A. Siņavskis sāka rakstīt prozu 50. gadu vidū. Pirmie stāsti iznāca Parīzē 50. gadu beigās (dati par stāstu iznākšanu dažādos avotos atškiras). Sk.: Климонтович, Н. 2005. Из Мордовии в Сорбонну. Синявского прославила его литературоведение. NG Ex Libris, 38 (340).
Ar viņa starpniecību uz ārzemēm tika izvesti arī tulkotāja un rakstnieka Jūlija Daniela (1925-1988) darbi, kas ar pseidonīmu Nikolajs Aržaks nāca klajā N̦ujorkā kopš 1958. gada. ${ }^{37}$ Pēc vairākiem gadiem abu rakstnieku publikāciju autorība tika atklāta, 1965. gadā vinusus arestēja un tiesāja par pretpadomju aǵitāciju un propagandu. Rakstniekiem tika piespriesti bargi sodi (A. Siñavskim - septini gadi, bet J. Danielam - pieci gadi nebrīvēe) ${ }^{38}$, taču viņi ieguva plašu ievērību un atbalstu Padomju Savienībā un Rietumvalstīis ${ }^{39}$, pieaugošu lasītāju pulku vin,pus un šaipus dzelzs priekškaram. Vinu darbu fragmentus lasīja arī radio "Brīvā Eiropa”, kas 70. gados uzsāka aizliegtās krievu literatūras lasījumu ciklu "С другого берега" ("From the Other Shore") ${ }^{40}$.

Pieejams: https://dlib.eastview.com [skatīts 21.11.2019.].

37 Даниэль Юлий Маркович. В кн.: Скатов, Н. Н. (ред.) 2005. Русская литература ХХ века. Прозаики, поэть, драматурги: Биобиблиографический словарь: в $3 \mathrm{~m}$. Москва: ОЛМА-ПРЕСС Инвест, 2005, с. 610-613. Pieejams: http://lib.pushkinskijdom.ru/LinkClick. aspx?fileticket = b0YDEQItxe0\%3d\&tabid $=10547$ [skatīts 21.11.2019].

38 Sasse, S. 2017. "Words Are No Deeds": Trials against Literature in the Soviet Union. In: Grüttemeier, R. (ed.) 2017. Literary Trials: Exceptio Artis and Theories of Literature in Court. New York, London, Bloomsbury Academic, p. 123.

39 Великанова, Е. (сост.), Еремина, Л. (ред.) 1989. Цена метафорь, или Преступление и наказание Синявского и Даниэля. Москва: Книга.

40 Corti, M. 2018. The Year 1968 in the History of Samizdat. Pieejams: https://www.coldwarradiomuseum.com/the-year-1968-in-the-history-ofsamizdat [skatīts 21.11.2019.]. "Radio Brīvā Eiropa/Radio Brīvība" sāka pārraides latviešu valodā tikai 1975. gadā. Sk.: Ekmanis, R. 2012. Radio Brīvā Eiropa / Radio Brīvība (RFE/RL) V. Jaunā Gaita, Nr. 269. Pieejams: https:// jaunagaita.net/jg269/JG269_Ekmanis.htm [skatīts 21.11.2019.]. 
A. Siņavskis un citi sodu izcietušie rakstnieki emigrēja uz ārzemēm, kur informēja Rietumvalstu sabiedrību par vārda brīvības ierobežojumiem un inteliǵences vajāšanu Padomju Savienībā. ${ }^{41}$ Tādēḷ PSRS GLP pastiprināja ienākošās kapitālistisko valstu literatūras kontroli PSRS robežpunktos, kā arī specfondos. ${ }^{42}$

\section{Latviešu emigrācijas literatūra - pilnīgas slepenības statusā}

1972. gada janvārī PSRS GLP pārstāvis apmeklēja cenzūras punktu Rīgas pasta pārvaldē jeb GLP specsektoru un konstatēja, ka latviešu emigrantu literatūra ar acīmredzamu pretpadomju saturu tiek klasificēta kā parasta kapitālistisko valstu literatūra, tas ir, saṇem vienu sešstūra zīmogu un tiek novirzìta divu bibliotēku (ZA FB un VB) specfondiem. ${ }^{43}$ Turklāt bija novecojusi instrukcija, kas reglamentēja emigrantu literatūras glabāšanu un izmantošanu. Vecākais cenzors Kārlis Ceipe (1910-1993), kā arī bibliotēku specfondu vadītāji joprojām ievēroja 1958. gada decembrī pieņemto LKP CK lēmumu "Par pasākumiem kontrpropagandas uzlabošanai latviešu emigrantu vidē" ${ }^{44}$, kas noteica

41 Kind-Kovács, F. 2014. Written Here, Published There: How Underground Literature Crossed the Iron Curtain, p. 56-57.

42 Информационная справка Главлита в ЦК КПСС о содержание западной печати, освежающей положение советской интеллигенции, и о политике КПСС в области литературы и искусства 29.6.1971. В кн.: Горяева, Т. (сост.) 1997. История советской политической цензуры: документы и комментария. Москва: РОССПЕН, c. 582-584.

43 Главлит ЛССР. [Ziņojums PSRS GLP sakarā ar LPSR GLP pārbaudi 1972. gada janv.] LVA, 917. f., 1.a apr., 113. 1., 9. lp.

44 Latvijas KP CK biroja lēmums 1958. g. 2. decembrī. Par pasākumiem kontrpropagandas uzlabošanai latviešu emigrantu vidē (bb. Veselovs, Vēvers, Pizāns, Kalnbērziņš). No: Strods, H. (sast.) 2005. Atbrīvotāji kā iekarotāji = Liberators as conquerors. Rīga: Latvijas Okupācijas muzeja biedrība, 197.-198. lpp. plašāku emigrācijā tapušās informācijas pieejamību kultūras darbiniekiem un zinātniekiem. ${ }^{45}$ Tādējādi pat četrdesmit procentiem emigrācijas literatūras nebija slepena glabāšanas režīma, tomēr tā bija novietota atsevišşi no pārējā krājuma un tai bija izsnieguma ierobežojumi.

Atbilstoši PSRS GLP prasībai cenzori nekavējoties pārskatīja ar vienu sešstūri apzīmogoto trimdas literatūru ZA FB un VB specfondos. ZA FB specfondā glabājās ap 1800 nosaukumu trimdas grāmatu (vairāk nekā 3000 eksemplāru), kā arī periodiskie izdevumi. ${ }^{46}$ Pēc GLP pārbaudes 150 grāmatas ar vienu sešstūra zīmogu ieguva vēl vienu sešstūri un nonāca pilnīgi slepenās literatūras glabātuvē. VB emigrācijas literatūras krājums specfondā bija krietni nabadzīgāks. 1972. gadā tajā bija 524 nosaukumi, kopā - vairāk nekā 1000 eksemplāru. ${ }^{47}$ Visi VB glabātie emigrācijas periodiskie izdevumi ieguva divus sešstūrus.

Pēc PSRS GLP pārbaudes cenzors K. Ceipe bija spiests doties pensijā, tika mainīta latviešu emigrācijas literatūras saṇemšanas un glabāšanas kārtība. ${ }^{48}$ LPSR GLP ar Austru Lucēviču (1927-2003) priekšgalā apturēja tās kā sevišḳi kaitīgas literatūras nodošanu VB. Lielākā daḷa trimdas literatūras ieguva divus sešstūra zīmogus un tika novirzīta ZA FB specfondam.

45 Главлит ЛССР. Секретарю ЦК КПЛ т. Дризул А. А. 12.07.1972. LVA, 917. f., 1.a apr., 115. 1., 24. 1p.

46 Turpat.

47 Turpat.

48 Главлит ЛССР. Дополнение к инструкции "О порядке выписки, хранения и использования литературы капиталистических стран”. LVA, 917. f., 1.a apr., 113. 1., 3.-4. 1p. 


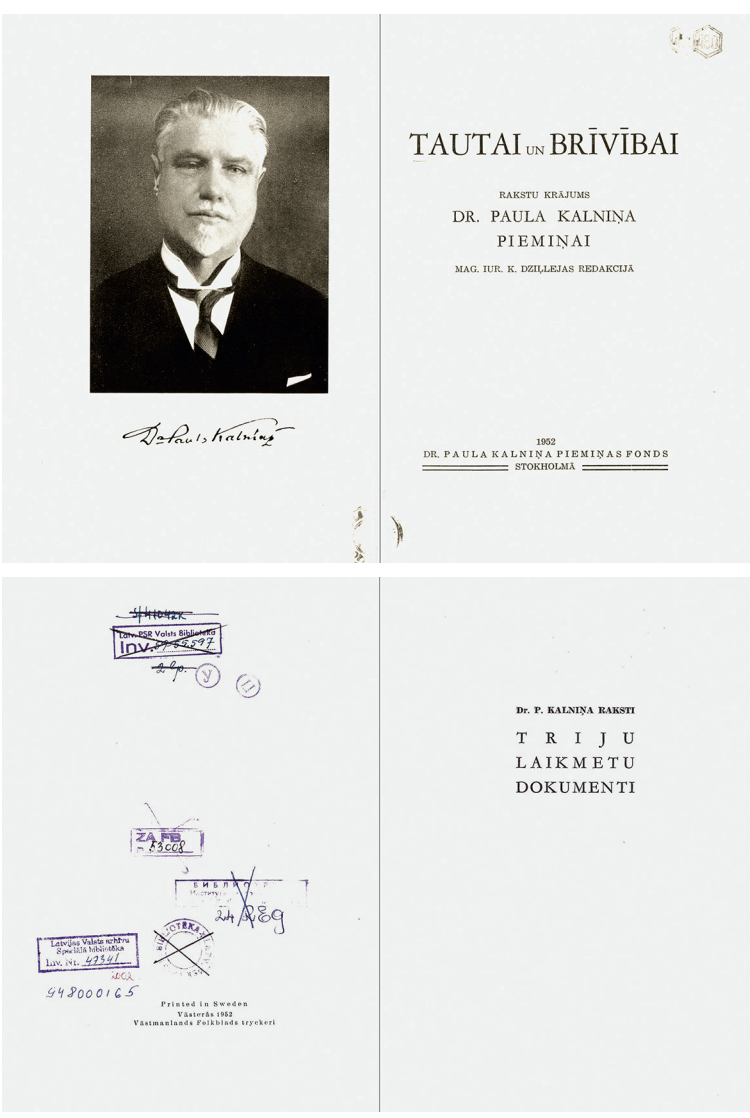

(2) Grāmata, kas vispirms ienākusi LPSR VB (mūsdienās LNB) specfondā, pēc tam kā pilnīgi slepena literatūra atdota Zinātṇu akadēmijas Fundamentālās bibliotēkas specfondam, vēlāk ieklauta LKP CK PVI specfondā. Patlaban glabājas LNA bibliotēkā
Tomēr LKP CK vēl kavējās ar oficiāla lēmuma pieņemšanu, kaut gan GLP tai jau bija piesūtījusi gatavu lēmuma projektu un vairākkārt atgādinājusi par jauna lēmuma nepieciešamību. ${ }^{49}$ 1973. gada 21. maijā LKP CK pieṇēma oficiālu lēmumu par latviešu emigrācijas literatūras turpmāko ceḷu Latvijā: tika noteikts, ka tās vienīgais san̄ēmējs būs ZA FB specfonds, kuram bija jāpārṇem arī nelielā iespieddarbu kopa no VB. ${ }^{50}$

ZA FB specfonda materiāli liecina, ka pirmo literatūras nodošanas aktu - par 1107 eksemplāriem - VB Komplektēšanas nodaḷas vadītājs sastādījis jau 1973. gada 24. aprīlī, tātad jau pirms LKP CK lēmuma. ${ }^{51}$ Dokumentā ietverti galvenokārt trimdas periodiskie izdevumi (“Jaunā Gaita”, "Labietis”, "Mazputniņš”, "Tilts", "Laiks" u. c.). Jādomā, ka šĩ jau 60. gados iznākusī literatūra nebija integrēta VB specfondā, bet glabājās VB Komplektēšanas nodalāa. Nākamais nodošanas akts sastādīts 1973. gada 30. jūlijā. 49 lappušu garajā sarakstā uzskaitītas 1073 vienības. 1973. gada 21. septembrī ZA FB saṇēma arī 24 eksemplārus nošu izdevumu un mikrofilmu. Tā kā abus pēdējos dokumentus sastādījuši VB specfonda darbinieki, acīmredzot tajos uzskaitītie iespieddarbi glabājās specfondā. Literatūras nodošanas akti liecina, ka VB kopējais trimdas grāmatu un periodikas krājums bija divkārt lielāks nekā LPSR GLP slēdzienā, proti, vairāk nekā 2200 eksemplāru, taču tikai puse bija apstrādāta un sagatavota izmantošanai specfondā.

ZA FB ieguvums no VB nebija būtisks, jo lielākā daḷa pārṇemtā krājuma bija "liekie"

49 Главлит ЛССР. [Ziṇojums PSRS GLP sakarā ar LPSR GLP pārbaudi 1972. gada janv.] LVA, 917. f., 1.a apr., 113. 1., 9. 1p.

50 Главлит ЛССР. Отчет по итогам контроля иностранной литературы за 1974 год. LVA, 917. f., 1.a apr., 128. 1., 3. lp.

51 LU AB Misina bibliotēka. LPSR ZA FB Literatūras speciālās glabāšanas nodaḷa. Dokumenti par specfondam nodotu literatūru. 
(trešie) eksemplāri, kas bija nolemti iznīcināšanai. ${ }^{52}$ Pēc LKP CK lēmuma arī ZA FB J. Misiṇa Latviešu literatūras nodaḷa bija spiesta specfondam atdot paprāvu daudzumu literatūras, kurā bija 40.-50. gadu trimdas izdevumi. ${ }^{53}$

Lai gan ZA FB bija kluvusi par galveno latviešu emigrācijas literatūras krātuvi, no pasta cenzūras punktā perlustrētajiem sūtījumiem tā saņēma mazāko daḷu; vismaz divreiz vairāk nonāca LKP CK. Pieklājīga artava tika atvēlēta arī LPSR VDK. Piemēram, 1974. gadā ZA FB ieguva 4 avīzes, 27 žurnālus, 33 grāmatas un 2 sīkiespieddarbus, LKP CK - 14 avīzes, 85 žurnālus, 6 grāmatas un 4 sīkiespieddarbus, bet VDK - 6 avīzes, 18 žurnālus, 64 grāmatas un 2 sīkiespieddarbus. ${ }^{54}$ Kā redzams, LKP CK tika novirzīts vairāk aktuālo periodisko izdevumu, kas bija nepieciešami tās Ārējo sakaru nodaḷai trimdas politisko norišu analīzei un ziņojumu sastādīšanai. Tādējādi LPSR ZA FB galvenais emigrācijas literatūras komplektēšanas avots bija starptautiskā grāmatu apmaiņa, nozīmīgu daḷu veidoja Latvijas komitejas sakariem ar tautiešiem ārzemēs piešksīrumi ${ }^{55}$, turklāt ienāca atsevišḳi trimdas latviešu dāvinājumi.

52 Klebā, J. 2007. Okupācijas varas cenzūras darbïba Latvijas Akadēmiskajā bibliotēkā, 83. lpp.

53 Turpat.

54 Главлит ЛССР. Отчет по итогам контроля иностранной литературы за 1974 год. LVA, 917. f., 1.a apr., 128. 1., 2. 1p.

55 LPSR ZA FB tos saṇēma kā galvenā emigrācijas literatūras glabātāja kopš 1958. gada decembra. Sk.: Latvijas KP CK biroja lēmums 1958. g. 2. decembrī. Par pasākumiem kontrpropagandas uzlabošanai latviešu emigrantu vidē (bb. Veselovs, Vēvers, Pizāns, Kalnbērzinšš). No: Strods, H. (sast.) 2005. Atbrīvotāji kā iekarotāji = Liberators as conquerors, 197.-198. 1pp.

\section{Latviešu emigrācijas literatūra - kontrpropagandas pastiprināšanai}

Mainoties PSRS vadībai, mainījās PSKP un attiecīgi LKP CK ideoloǵiskā darba akcenti. 1982. gada novembrī par PSKP CK ǵenerālsekretāru kḷuva līdzšinējais PSRS VDK vadītājs Jurijs Andropovs (1914-1984), kurš PSKP CK plēnumā 1983. gada jūnijā par svarīgāko ideologisko uzdevumu noteica efektīvas kontrpropagandas $^{56}$ sistēmas izveidi un "melīgās, graujošās" imperiālistiskās propagandas atmaskošanu. ${ }^{57}$ Šo ideolog̣isko virzību sākotnēji ievēroja arī Mihails Gorbačovs, kurš PSKP CK ǵenerālsekretāra amatu ieguva 1985. gada martā. Acīmredzot kontrpropaganda tika uzskatīta par drošāko līdzekli pret "ienaidnieku” ASV un kapitālistisko valstu - informatīvo ietekmi. Par vienu no LPSR kontrpropagandas centriem bija jākḷūst LKP CK PVI. ${ }^{58}$ Lai "[..] paaugstinātu partijas vēstures pētījumu lomu

56 Dienvidkalifornijas Universitātes Annenberga komunikācijas un žurnālistikas skolas profesors Nikolass Kalls (Nicholas J. Cull) norāda, ka daudzos gadījumos informācija, ko uzskatām par propagandu, patiesībā ir kontrpropaganda. Viņš izškir stratēǵisko kontrpropagandu komunikācijas politiku, kas vērsta pret ienaidnieka propagandistisko darbību kopumā, - un taktisko kontrpropagandu - vēstījumu vai to kopu, kas tiek izmantota pret konkrētu pretinieka vēstījumu vai aktivitāti. Profesors norāda, ka kontrpropagandā tiek izmantotas dažādas metodes, taču galvenā ir cenzūra - pretinieku ideju cirkulēšanas aizliegums noteiktā sabiedrībā ar preses brīvības ierobežojumu, radio pārraižu traucējumu, interneta ugunsmūru izveidi, likumdošanu un citu līdzīgu aktivitāšu palīdzību. Cull, J. N. 2015. Counter Propaganda: Cases from US Public Diplomacy and beyond. Legatum Institute's Transitions Forum. Pieejams: https://lif.blob.core.windows.net/lif/docs/defaultsource/publications/counter-propaganda---casesfrom-us-public-diplomacy-and-beyond-july-2015pdf.pdf?sfvrsn $=8$ [skatīts 21.11.2019.].

57 Zīle, L. 1984. Latvijas Komunistiskajai partijai - 80 . Rīga: Avots, 117. lpp.

58 ИИП ЦК КПЛ. О работе ИИП ЦК КП Латвии филиала ИМЛ при ЦК КПСС. 30.01.1985. LVA, PA-200. f., 11. apr., 39. 1., 17. 1p. 
cīṇā pret antikomunismu, buržuāzisko nacionālismu un PSKP vēstures falsifikāciju", 1983. gadā PSKP CK Marksisma-ḷeninisma institūta komisija no Maskavas ierosināja LKP CK PVI bibliotēkā krājumu papildināt ar ārzemju literatūru par Latviju jeb letiku ${ }^{59}$, kaut tajā jau iepriekš bija ienākuši emigrantu izdevumi, piemēram, ASV latviešu sociāldemokrātu avīze "Strādnieks". ${ }^{60}$ Steigšus no kopējā krājuma tika atlasīti ierobežotas pieejamības izdevumi (specfonds), sāktas sarunas ar LKP CK Propagandas un ag̣itācijas nodaḷas vadītāja vietnieci, kādreizējo LPSR GLP vadītāju Austru Lucēviču. ${ }^{61}$ LKP CK Propagandas un aǵitācijas nodaḷa un tieši A. Lucēviča bija atbildīga par pilnīgi slepenās latviešu emigrācijas literatūras izmantošanu; viņa izvērtēja zinātnieku pieprasījumus un sniedza aț̣aujas konkrētu darbu lasīšanai. Pilnīgi slepenā specfonda izmantošanai zinātniekiem bija nepieciešams ne tikai savas iestādes vadītāja parakstīts iesniegums ar precīzi formulētu pētniecības tematu un konkrētu iespieddarbu sarakstu, bet arī vietējās partijas organizācijas sekretāra un LKP CK Propagandas un ag̣itācijas nodalias akcepts.

Tā kā LKP CK bija atbalstījusi PSKP CK Marksisma-l,eñinisma institūta rekomendāciju par specfonda izveidi, 1985. gada 2. jūlijā PVI vadība tai iesniedza nepieciešamo priekšdarbu sarakstu. LKP CK bija ne tikai jāpieņem lēmums par specfonda izveidi, bet arī jāparūpējas par institūta štatu saraksta papildināšanu ar specfonda vadītāja amata vienību, par specfonda

59 иИП ЦК КПЛ. Мероприятия по устранению недостатков, отмеченных при проверке работы Института истории партии при ЦК КП Латвии комиссией ИМЛ при ЦК КПСС. LVA, PA-200. f., 11. apr., 4. 1., 60. lp.

60 Zīle, L̦. (red.) 1980. Latvijas KP CK Partijas vēstures institūts - PSKP CK Marksisma-l̦ninisma institūta filiāle - Институт истории партии при ЦК КП Латвии - филиал Института марксизмаленинизма при ЦК КПСС: 60. Riga: Avots, 51. lpp.

61 иИП ЦК КПЛ. Протокол заседания дирекции № 8. 31.10.1984. LVA, PA-200. f., 11. apr., 4. 1., 47. lp. krātuves un lasītavas remontu. CK Propagandas un aǵitācijas nodaḷai bija apstiprināms specfonda komplektēšanas profils - "literatūra par antikomunisma, antisovjetisma, buržuāziskā nacionālisma problemātiku, sevišksi LKP CK un PSKP vēstures falsifikācijas jomā [..], nodrošinot institūtu ar periodiskajiem izdevumiem, kuros rodami atbilstoši materiāli" ${ }^{2}$. Savukārt LPSR MP bija jāizskata attiecīgās literatūras iegādes finansēšanas iespējas ${ }^{63}$, jo kapitālistisko valstu izdevumi bija nopērkami tikai par valūtu, ja vien nebija organizēta grāmatu apmaiņa ar šìm valstīm.

Lēmumu par PVI bibliotēkas specfonda izveidi LKP CK pieñēma 1985. gada 8. augustā. Specfondā tika atḷauts glabāt ne tikai tā sauktās buržuāziskās Latvijas periodiskos izdevumus, bet arī latviešu "reakcionārās" emigrācijas literatūru. ${ }^{64}$ Specfonda kopapjoms tika lēsts ap 12000 vienību, tādēḷ PVI pieprasīja divas jaunas štata vienības (speciāli glabājamās literatūras nodaḷas vadītāju un lasītavas vadìtāju). ${ }^{65}$ Faktiski tika atvēlēta viena štata vienība, jo pagaidām krājuma apjoms bija neliels.

1986. gada martā PVI speciālās glabāšanas fonda jeb specfonda vecākās bibliotekāres amatā tika pienemta A. Lucēviča. ${ }^{66}$ Būdama Galvenās literatūras pārvaldes vadītāja no 1971. līdz 1981. gadam un vēlāk LKP CK Propagandas un aǵitācijas nodaḷas vadītāja vietniece, viņa bija ieguvusi pieredzi emigrācijas izdevumu izplatības apkarošanā okupētajā Latvijā 70. gados un rakstījusi izvērstus ziņojumus LKP CK par pretpadomju izpausmēm kā vietējā, tā emigrācijas

62 ИИП ЦК КПЛ. Центральному Комитету

Компартии Латвии. 2.7.1985. LVA, PA-200. f., 11. apr., 39. 1., 54. 1p.

63 Turpat.

64 ИИП ЦК КПЛ. Управлению делами ЦК Компартии Латвии. 16.08.1985. LVA, PA-200. f., 11. apr., 39. 1., 62. 1p.

65 Turpat.

66 ИИП ЦК КПЛ. Приказ директора Института № 17 3.03.1986. LVA, PA-200. f., 13. apr., 24. 1., 17. 1 . 
latviešu literatūrā. ${ }^{67}$ PVI vadība A. Lucēvičas raksturojumā 1987. gadā uzsvēra, ka "Valsts noslēpumu aizsardzības orgānos viņa izpildījusi savus dienesta pienākumus ar radošu aktivitāti un nepieciešamo politisko asumu”, bibliotekāres amatā saglabājot "augstu partejisko principialitāti un politisko sagatavotību". ${ }^{68}$

Jau 1986. gada rudenī tika stingri reglamentēts specfonda pastāvīgo lietotāju loks: līdzstrādnieki, kuriem bija uzticēts pētnieciskais un izglìtojošais darbs kontrpropagandas nozarē. Viṇu skaitā bija vairāki administrācijas darbinieki, sektoru vadītāji un vecākie zinātniskie līdzstrādnieki - vairāk nekā puse institūta zinātniskā personāla. ${ }^{69}$ Lai gan specfondam bija atvēlēta atsevišksa krātuve un lasītava, aizliegto literatūru bija l̦auts lasīt arī darba kabinetā, katras dienas beigās to nododot specfonda krātuvē. Tā kā pētnieku piekḷuve specfondam netika diferencēta atkarībā no literatūrai pieškirtās kategorijas (slepena vai pilnīgi slepena), secināms, ka PVI pētniekiem tika noteikts privilegèets stāvoklis okupētās Latvijas zinātnes sistēmā. Viṇi drīkstēja lasīt savā darba kabinetā "visreakcionārākos" latviešu emigrācijas periodiskos izdevumus, kas citu institūciju pētniekiem netika atlauts (viṇi tos varēja lasīt tikai uz vietas ZA FB specfondā; par LKP CK PVI specfonda atvērtību citu iestāžu līdzstrādniekiem ziņu trūkst).

Arī ZA FB pilnīgi slepenās literatūras lasītāju skaitā dominēja vēsturnieki - LPSR ZA humanitāro un sociālo zinātṇu institūtu līdzstrādnieki, P. Stučkas Latvijas Valsts universitātes

67 ИИП ЦК КПЛ. Характеристика А. А. Луцевич. 26.01.1987. LVA, PA-200. f., 16. apr., 12. 1., 13. 1p. 68 Turpat.

69 ИИП ЦК КПЛ. Приказ директора Института № 63 20.11.1986. LVA, PA-200. f., 13. apr., 24. 1., 68. $1 \mathrm{p}$.
(LVU, mūsdienās - Latvijas Universitāte) Vēstures un filozofijas fakultātes, A. Pelšes Rīgas Politehniskā institūta (mūsdienās - Rìgas Tehniskās universitātes) PSKP vēstures katedras, kā arī Daugavpils Pedagoǵiskā institūta mācībspēki. ${ }^{70}$ Kopējā ZA FB specfonda lasītāju pulkā vinuu bija maz (ap 30 ațlauju no 201), turklāt viņu pētniecības nozare - vēsture - noteica diezgan šauru izmantojamo iespieddarbu tematiku: redzamāko trimdas darbinieku memuāri, monogrāfijas par Latvijas vēsturi, politiku, religiju, rakstu krājums "Arhīvs" (Melburna, kopš 1960. gada), uzziņu izdevums "Latvju enciklopēdija" (Stokholma: Trīs zvaigznes, 1950-1955, papildsēj. 1962. g.), kā arī prese. Pieprasītāko autoru skaitā - trimdas vēsturnieki: Arnolds Aizsilnieks (1898-1982), Edgars Andersons (1920-1989), Edgars Dunsdorfs (1904-2002), Arnolds Spekke (1887-1972), Ādolfs Šilde (1907-1990), Arveds Švābe (1888-1959) un Uldis Ģērmanis (1915-1997). Lasītāju iesniegumiem pievienotajos literatūras pieprasījumos atrodam arī ievērojamu latviešu politiķu Miḳeḷa Valtera (1874-1968), Alfrēda Bērziña (1899-1977), Ernesta Voldemāra Bastjān,a (1884-1975), Fēliksa Cielēna (1888-1964), Oskara Dankera (1883-1965) u. c. - atmiņu grāmatas. Vienā otrā sarakstā iekḷauti Zentas Mauriņas (1897-1978) un Paula Jureviča (1891-1981) eseju izdevumi, kā arī Alfrēda Dziḷuma (1907-1976) romānu publicējumi, taču lielākoties pieprasītās literatūras saraksti ir līdzīgi, ietver vienus un tos pašus iespieddarbus, acīmredzot par tiem akadēmiskajā vidē cirkulēja informācija. Domājams, pat LPSR ZA īstenajiem locekḷiem trūka izsmelıšas informācijas par emigrācijas literatūru, jo vinịi to drīkstēja izmantot tikai selektīvi, proti, saskaṇā ar iesniegumā sniegto iespieddarbu sarakstu un LKP CK rezolūciju.

1985. gadā tika ierosināta ZA FB specfondā glabātās PSKP un LKP vēstures literatūras

70 LU AB Misina bibliotēka. LPSR ZA Literatūras speciālās glabāšanas nodaḷas lasītāju iesniegumi, 1985. [gads]. 
nodošana PVI bibliotēkas specfondam pēc institūta jaunās ēkas uzcelšanas. ${ }^{71}$ Tolaik institūta jaunā nama būvniecība vēl nebija uzsākta. Drīz radās ideja koncentrēt latviešu emigrantu iespieddarbus LKP CK PVI bibliotēkā, kas pārṇemtu arī atbilstošo, gadiem veidoto ZA FB specfonda dalı (tā komplektēšana tomēr noritētu ZA FB, jo tai bija atbilstošs apmaiņas partneru loks latviešu mītnes zemēs). ${ }^{72}$ Tādējādi tika apdraudēta jau tā trūcīgā emigrācijas literatūras krājuma saglabāšana un attīstība, kā arī pieejamība okupētajā Latvijā. Tādēl 1986. gada 13. maijā ZA iesniedza LKP CK ziņojumu, kur norādīja, ka emigrācijas literatūra ir ZA FB letikas krājuma neatn,emama sastāvdal,a, kas kalpo padziḷinātai latviešu kultūras mantojuma pētniecībai. Uzkrāti jau 10000 trimdas iespieddarbu, kas iegūti galvenokārt grāmatu apmaiṇā ar 20 partneriem VFR, Zviedrijā, ASV, Kanādā un Austrālijā. ${ }^{73}$ Tika uzsvērts, ka ZA darbojas Latviešu literatūras un mākslas mantojuma pētīšanas un izdošanas zinātniskā padome, kas LKP CK uzdevumā izvērtē arī ārzemju latviešu autoru (Zenta Mauriņa, Mārtiņš Zīverts) daiḷdarbus. Turklāt ZA Sabiedrisko zinātṇu zinātniskās informācijas centrs sastādīja ārzemju letikas referatīvos izdevumus (ierobežotas pieejamības izdevumi, kuros apkopota bibliogrāfiskā informācija, anotācijas un pārskati par noteiktas tematikas publikācijām), kas tika iekḷauti vienotajā PSRS ZA datubāzē. Iesniegumā ZA piedāvāja šādu kompromisu: 1) atdot PVI specfondam emigrācijas literatūras otros eksemplārus no ZA FB krājuma (dubleti veidoja aptuveni trešo daļu), 2) palīdzēt PVI specfondam

71 иИП ЦК КПЛ. Центральному Комитету Компартии Латвии. 2.7.1985. LVA, PA-200. f., 11. apr., 39. 1., 54. 1p.

72 Академия наук Латвийской ССР. Первому секретарю ЦК Компартии Латвии тов. Пуго Б. К. 13.05.1986. LVA, PA-101. f., 59. apr., 132. 1., 13. lp.

73 Turpat. trūkstošo izdevumu komplektēšanā. ${ }^{74}$ LKP CK (faktiski - Propagandas un ağitācijas nodala) piekrita ZA piedāvātajam risinājumam, tomēr norādīja, ka turpmāk ZA FB saņems tikai tos emigrācijas izdevumus, kas ienāks grāmatu apmaiņas ietvaros, pārējie tiks novirzīti PVI. ${ }^{75}$

Tādējādi arī FB varēja turpināt trimdas literatūras krājuma komplektēšanu un glabāšanu, kaut arī tai nācās atteikties no dubletiem, kas kḷuva par LKP PVI bibliotēkas specfonda latviešu emigrācijas literatūras kolekcijas pamatu. 3 Vismaz vienā bibliotēkā apkopota latviešu literatūras krājuma esamība bija svarīga pētniecībā, jo l̦āva kaut nelielai zinātnieku daḷai apjaust latviešu zinātniskās domas pēctecību, ietekmju un viedokḷu dažādību. Lai arī to nebija iespējams pagaidām publicēt, šaurākā cilvēku lokā, kā liecina vēsturnieku iesniegumi specfonda izmantošanai, zināšanu pārnese tomēr bija iespejjama. ${ }^{76}$

LPSR GLP informācija liecina, ka pastā konfiscēto sūtijumu sadale tomēr būtiski nemainījās, turklāt šis komplektēšanas avots nebija pietiekams nedz vienam, nedz otram specfondam. Piemēram, 1986. gadā ZA FB sañēma 58 periodikas vienības un četras grāmatas, LKP CK PVI - 31 avīzi un vienu grāmatu ar diviem sešstūra zīmogiem. ${ }^{77} 1987$. gadā ZA FB saṇēma 31 periodikas vienību un divas grāmatas ar diviem sešstūra zīmogiem, bet PVI - 53 periodikas vienības un trīs grāmatas, kas bija ieguvušas pilnīgas slepenības

74 Академия наук Латвийской ССР. Первому секретарю ЦК Компартии Латвии тов. Пуго Б. К. 13.05.1986. LVA, PA-101. f., 59. apr., 132. 1., 13. lp.

75 ЦК Компартии Латвии. Об оказании помощи в создание и дальнейшем развитие специального хранения Института истории партии при ЦК Компартии Латвии. 19.06.1986. LVA, PA-101. f., 59. apr., 132. 1., 15. 1p.

76 LU AB Misina bibliotēka. LPSR ZA Literatūras speciālās glabāšanas nodaḷas lasītāju iesniegumi, 1985.-1990. [gads].

77 Главлит ЛССР. Сводка о работе пункта при почтамте г. Риги за 1986 год. 6.01.1987. LVA, 917. f., 1.a apr., 208. 1., 45. 1p. 
zīmogus. $^{78}$ LKP CK un LPSR VDK guvums bija lielāks. LKP CK 1987. gadā saṇēma kopumā 89 avīžu eksemplārus, to skaitā 84 ar diviem sešstūra zīmogiem, savukārt VDK - vairāk nekā 200 periodikas vienību, to skaitā 188 ar diviem sešstūriem, kā arī 37 grāmatas, starp tām 10 ar diviem sešstūra zīmogiem. ${ }^{79}$

Paradokss - 1986. gadā divu trimdas valodnieču grāmatas ${ }^{80}$ ieguva nevis sešstūra, bet pat trijstūra zīmogu, "jo neietvēra pretpadomju informāciju"81, tās varēja novirzìt glabāšanai vispārpieejamā krājumā. Turpretī lielākā daḷa preses aizvien tika atzīta par pilnīgi slepenu tādēl, ka "antikomunisms un antisovjetisms" joprojām bija tās pamatiezīme. ${ }^{82}$ Tā vēstīja gan par Latvijas nelikumīgu iekḷaušanu PSRS, Latvijas militarizāciju un rusifikāciju; iedzīvotāju pieaugošo pretestību un citiem padomju varai nevēlamiem jautājumiem. ${ }^{83} 4$

78 Главлит ЛССР. Сводка о работе пункта при почтамте г. Риги за 1987 год. 14.01.1988. LVA, 917. f., 1.a apr., 212. 1., 36. lp.

79 Главлит ЛССР. Сводка о работе пункта при почтамте г. Риги за 1987 год. 14.01.1988. LVA, 917. f., 1.a apr., 212. 1., 36. lp.

80 V. Rūkes-Dravinas "Cilvēks un daba latviešu tautasdziesmās" (Stokholma: Artilett, 1986), V. Rūḳes-Draviñas un J. Tāra "Krišjānạa Barona Dainu parks" (Stockholm: Artilett, 1985), kā arī Baibas Metuzāles-Kangeres "A derivational dictionary of Latvian $=$ Latviešu valodas atvasinājumu vārdnīca" (Hamburg: Buske, 1985).

81 Главлит ЛССР. Секретарю ЦК КПЛ Горбунову А. В. и заместителю председателя Совета Министров ЛССР тов. Барткевичу Л. Л. О контроле эмигрантской литературы, поступавшей в республике по открытым почтовым каналам 2.02.1987. LVA, 917. f., 1.a apr., 210. 1., 7. lp.

82 Главлит ЛССР. Отчет по контролю бандеролей, поступивших из-за границы с иностранной литературой на латышском языке за 1986 год. LVA, 917. f., 1.a apr., 208. 1., 37. lp.

83 Главлит ЛССР. Сводка о работе пункта при почтамте г. Риги за 1986 год. 6.01.1987. LVA, 917. f., 1.a apr., 208. 1., 45. 1p.

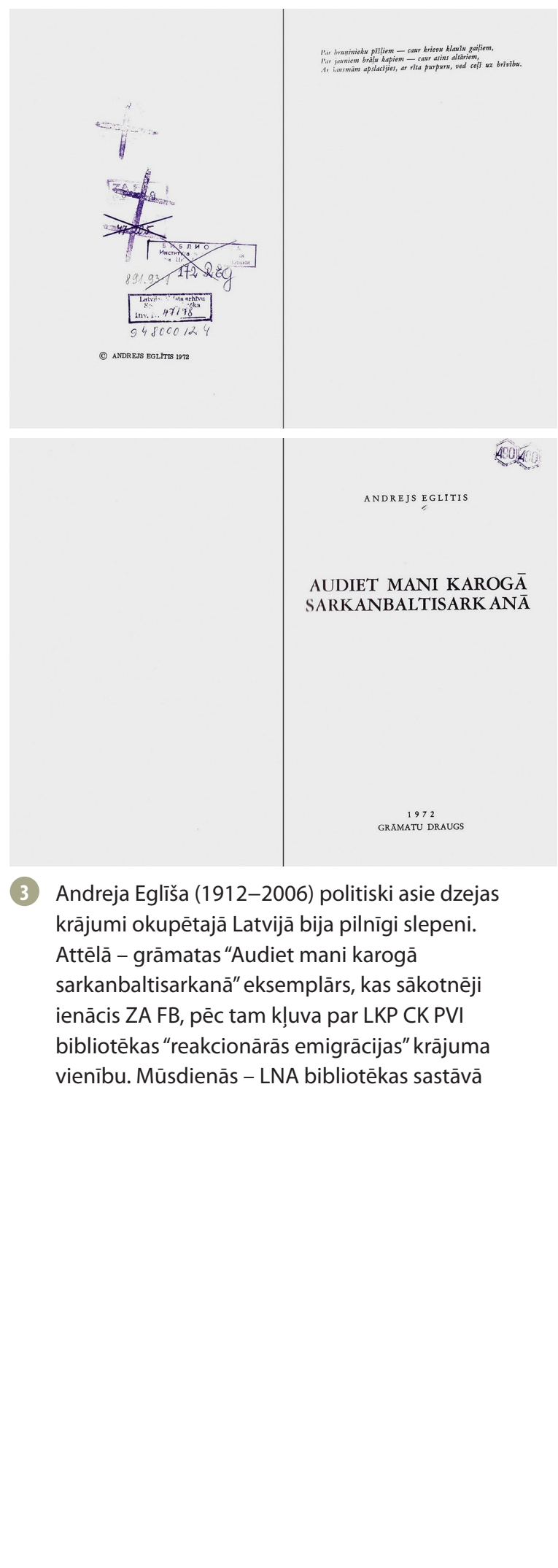


ES NEPIEVIENOJOS NEVIENAM TEVIS TEIKTAM VȦRDAM, BET ES AIZSTẢVĒSU LIDZ NÃVEI TAVU TIESIBUU TOS PATEIKT.

Rakstu krājums "Jaunā Gaita". 3. gadagājums, 14. nr., 1958. gada marts-aprïlis. LPSR ZA FB eksemplārs, mūsdienās atrodams LU AB
Latvijā izveidojās absurda, tomēr komunistiskajam režīmam tipiska situācija: oficiāli latviešu emigrācijas literatūra bija pilnīgi slepena, sabiedrībai radot iespaidu, it kā tās nebūtu vispār, taču privāti - no rokas rokā cirkulēja gan rakstu krājums "Jaunā Gaita", gan citi preses izdevumi, gan grāmatas, bija iespēja klausīties radiopārraides un iegūt trimdas latviešu mūzikas skaņu ierakstus. ${ }^{84}$

1988. gada martā arī VB Speciāli glabājamās literatūras nodaḷa saṇēma pirmās latviešu emigrācijas grāmatas, ko tūlīt pat novirzìja inventarizācijai Ārzemju literatūras komplektěšanas nodaḷāa. ${ }^{85}$ (5) Tomēr pilnīgi slepenie preses izdevumi vēl neienāca, lai arī virkne latviešu emigrācijas žurnālu un pat avižz tika atbrīvota no pilnīgas slepenības statusa, ieguva tikai vienu sešstūra zīmogu un bija glabājama un lasāma specfondos ierastajā kārtībā. Lìdz pat 1989. gada oktobrim politiski asākie emigrācijas laikraksti, piemēram, "Brīvā Latvija", sañēma sešstūra zīmogu ${ }^{86}$ Tikai 1990. gadā ZA FB varēja bez ierobežojumiem nodot emigrantu "pretpadomju" literatūras krājumu J. Misiṇa Latviešu literatūras nodaḷai (1992. gadā tā atguva nosaukumu - Misiņa bibliotēka). Savukārt LKP CK PVI bibliotēkas specfonds pārtrauca darbu īsi pirms Latvijas valsts neatkarības atjaunošanas 1990. gada

84 Šĩ raksta autore izstrādājusi pētījumu par trimdas literatūras neoficiālo apriti okupētajā Padomju Latvijā: Dreimane, J. From Secrecy to Openness: Restricted Collections of Libraries and Unofficial Culture in Latvia in the1970s and 1980s. Raksts iesniegts un akceptēts publicēšanai Herdera institūta (Marburga) izdevumā "Zu Geschichte und Provenienz Baltischer Kunst- und Kulturhistorischer Sammlungen im 19. und 20. Jahrhundert".

85 LPSR VB. Akts Nr. 1 25.03.1988. [par trimdas] grāmatu nodošanu Ārzemju literatūras komplektēšanas nodaḷai. LNB, Reto grāmatu un rokrakstu krājums, Latvijas Valsts bibliotēkas specfonda nodalia RXA 324, Nr. 35.

86 Pilns laikraksta nosaukums "Brīvā Latvija: Apvienotā "Londonas Avīze" un "Latvija"'. Sk. tā 1989. gada oktobra numurus. Pieejams: https:// periodika.lndb.lv/ 


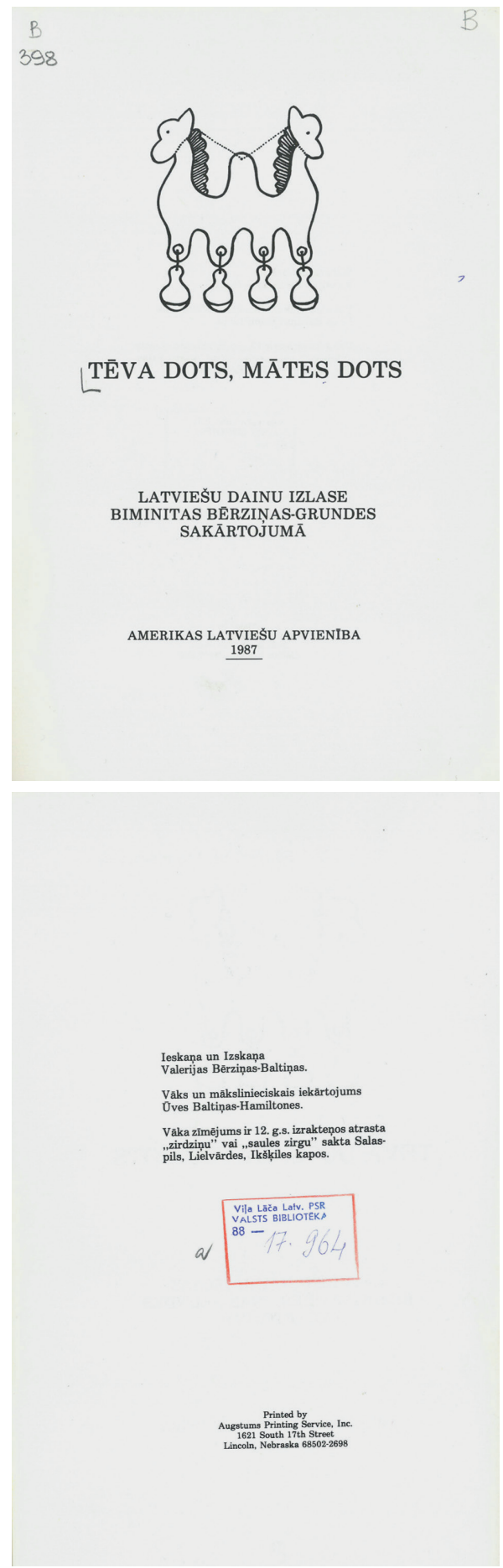

(5) Viena no pirmajām trimdas grāmatām, ko VB sañēma 1988. gada martā. Mūsdienās atrodama LNB Letonikas un Baltijas centrā aprīlī. ${ }^{87}$ 1991. gadā uzsākta krājuma integrācija Latvijas Nacionālā arhīva bibliotēkā, kas turpina glabāt no tās pārn,emto nelielo trimdas grāmatu kopu, diemžēl apjomīgais periodisko izdevumu fonds nav paturēts. Zudībā gājusi arī LKP CK PVI specfonda dokumentācija, acīmredzot A. Lucēviča, būdama kādreizējā LPSR GLP vadītāja, rūpīgi ievēroja norādījumu par tās iznīcināšanu.

\section{Nobeigums}

Sevišḳi "kaitīgās" emigrācijas literatūras glabāšanas un izmantošanas politika okupētajā Latvijā demonstrē padomju varas galveno stratēǵiju "pretpadomju" informācijas apkarošanā: tai tika noteikts pilnīgas slepenības režīms, kas nozīmēja tās apriti ḷoti šaurā cilvēku lokā, kuram bija "tiesības zināt". Līdz 1985. gadam šì literatūra bija izmantojama gandrīz vai vienīgi kontrpropagandai, šim mērķim, saprotams, bija jākalpo arī zinātnei. Plašākai sabiedrībai tika radīts iespaids, itin kā emigrācijas literatūra nepastāvētu vispār, jo tika liegta pieeja pat apolitiskiem izdevumiem. Ierobežotā piekḷuve specfondiem, tajā skaitā emigrācijas literatūrai, apstiprina faktu: PSRS Konstitūcijā deklarētā "tautas vara" nepastāvēja arī galvenā nemateriālā resursa - informācijas - pieejamībā un, tāpat kā citās nozarēs, bez seviškiem ierobežojumiem to varēja sanemt tikai Komunistiskās partijas elite un neliela zinātnieku daḷa. Informācijas vakuumu par norisēm trimdas sabiedrībā padomju vara centās aizstāt ar dezinformāciju savas valsts iedzīvotājiem, savukārt emigrācijā dzīvojošiem latviešiem tika veidots maldīgs priekšstats par situāciju Latvijā.

87 LKP CK Partijas vēstures institūta bibliotēkas speciālās glabāšanas fonda vecākās metodiḳes A. Lucēvičas iesniegums direktorei L̦. Zīlei par atbrīvošanu no darba "sakarā ar darba apjoma izbeigšanos" 1990. gada 1. aprīlī. Atbrīvota no darba pēc pašas vēlēšanās 1990. gada 15. aprīî̄. LVA, PA-200. f., 16. apr., 12. 1., 15. lp. 
Diemžēl padomju dezinformācijas sistēma līdz šim nav izzināta, tā būtu tālāku pētījumu objekts. Tomēr vēlreiz jāuzsver, ka okupētajā Latvijā neformālajā komunikācijā, pat privātajā korespondencē arvien brīvāk iegūstamā informācija ne tikai par latviešu emigrantu dzīvi t. s. kapitālisma valstīs, bet arī par Latvijas vēsturi disonēja ar plašsaziņas līdzekḷos un oficiālos saietos pausto melīgo propagandu. Tikai kopš 1986. gada sabiedrībai bija l̦auts limitētās devās iepazìt atsevišksus trimdas autorus un vinu darbus - latviešu literārā mantojuma apguves nolūkos, taču līdz pat okupācijas beigām nebija pilnīgi brīvas pieklıves trimdas presei.

Grāmatām un presei ar pilnīgas slepenības zīmogiem mūsdienās, trīsdesmit gadus pēc Latvijas valstiskuma atdzimšanas, ir īpaša nozīme. Apzīmogotie iespieddarbi veido nelielu latviešu emigrācijas izdevumu kopu, kura padomju gados izkḷuva cauri PSRS, vēlāk LPSR VDK kontroles sietam un nonāca dažās privilegètās Latvijas bibliotēkās - atškirīīā no daudziem tūkstošiem "lieko" eksemplāru, kas, nesasnieguši adresātus, tika nolemti iznīcībai. Šì kopa

\section{LITERATŪRA}

Bērzinsš, U. 2013. Varbūt šoreiz? Jaunā Gaita, Nr. 274. Pieejams: https://jaunagaita.net/jg274/JG274_ Pragas-pavasaris.htm [skatīts 21.11.2019.].

Corti, M. 2018. The Year 1968 in the History of Samizdat. Cold War Radio Museum, 2018. Pieejams: https:// www.coldwarradiomuseum.com/the-year-1968-inthe-history-of-samizdat [skatīts 21.11.2019.].

Cull, N. J. 2015. Counter Propaganda: Cases from US Public Diplomacy and beyond. Legatum Institute's Transitions Forum. Pieejams: https://lif.blob.core.windows.net/ lif/docs/default-source/publications/counterpropaganda---cases-from-us-public-diplomacyand-beyond-july-2015-pdf.pdf?sfvrsn $=8$ [skatīts 21.11.2019.].

Ekmanis, R. 2012. Radio Brīvā Eiropa / Radio Brīvība (RFE/RL) - V. Jaunā Gaita, Nr. 269. Pieejams: https:// ir Padomju Savienības un ASV ideologiskā kara liecība, kas l,auj precizēt un analizēt plašo literatūras spektru, kurš faktiski bija aizliegts Padomju Latvijā, taču nebija fiksēts nedz aizliegto grāmatu preses sarakstos, nedz bibliotēku oficiālajā lietvedībā, kas nebija pilnīgi slepena. Visbeidzot - liela daḷa šìs literatūras, īpaši prese, atsevišķos gadījumos okupētajā dzimtenē patiešām iesūtīta lielākā eksemplāru skaitā bez iepriekšējas vienošanās ar adresātiem, ir bagātīgs trimdas latviešu pretpadomju kustības izzinas avots, ko labi apzinājās un izmantoja arī padomju okupācijas vara.

Pētījums izstrādāts Valsts pētījumu programmas "Latvijas mantojums un nākotnes izaicinājumi valsts ilgtspējai" projekta "Dokumentārā mantojuma izpētes nozìme, veidojot sinerǵijas starp pētniecību un sabiedrību" ietvaros.

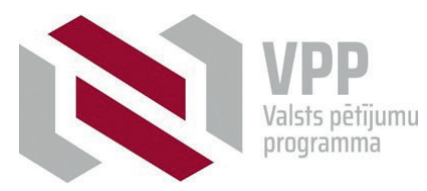

jaunagaita.net/jg269/JG269_Ekmanis.htm [skatīts 21.11.2019.].

Finn, P., Couvée, P. 2015. We tore a big hole in the Iron Curtain. In: The Zhivago affair: the Kremlin, the CIA, and the battle over a forbidden book. New York: Vintage Books.

Grybkauskas, S. 2007. The Soviet dopusk System as Society Control Lever in the Industry of Soviet Lithuania during 1965-1985. No: Latvija un Austrumeiropa 20. gadsimta 60.-80. gados: starptautiskās konferences referāti. 2006. gada 10. oktobris, Riga = Latvia and Eastern Europe in the 1960s-1980s: materials of international conference 10 October 2006. Riga: Latvijas Vēsturnieku komisija, Latvijas Universitātes Latvijas vēstures inst., Latvijas Kara muzejs, 79.-86. Ipp. 
Harrison, M. 2013. Accounting for Secrets. The Journal of Economic History, 73 (4), p. 1017-1049. Pieejams: www.jstor.org/stable/24551010 [skatīts 21.11.2019.].

Hutchings, R. 1987. Soviet Secrecy and Non-secrecy. Totowa, New Jersey: Barnes \& Noble books.

Izvilkumi no Latvijas Padomju Sociālistiskās Republikas kriminālkodeksa. No: Vīksne, R., Kangeris, K. (red.) 1999. No NKVD līdz KGB: politiskās prāvas Latvijā 1940-1986. Rīga: Latvijas vēstures institūta apgāds, 964. Ipp.

Jones, D. 2001. The Cold War. In: Jones, D. (ed.) Censorship: A World Encyclopedia. London; Chicago: Fitzroy Dearborn.

Katajs, E. 1973. Ārzemju literatūra bibliotēkas fondos. No: Bibliotēka - zinātnei. Rīga: Zinātne, 64.-65. Ipp.

Kind-Kovács, F. 2014. Written Here, Published There: How Underground Literature Crossed the Iron Curtain. Budapest: Central European University Press.

Klebā, J. 2007. Okupācijas varas cenzūras darbība Latvijas Akadēmiskajā bibliotēkā. Maǵistra darbs. Rīga: LU.

Latvijas KP CK biroja lēmums 1958. g. 2. decembrī. Par pasākumiem kontrpropagandas uzlabošanai latviešu emigrantu vidē (bb. Veselovs, Vēvers, Pizāns, Kalnbērziņš). No: Strods, H. (sast.) 2005. Atbrīvotāji kā iekarotā$j i=$ Liberators as conquerors. Rīga: Latvijas Okupācijas muzeja biedrība, 197.-198. Ipp.

Latvijas PSR Valsts drošības komitejas zinātniskās izpētes komisija. 2018. Pārskats par periodu no 2017. gada 1. janvāra lïdz 2018. gada 31. maijam. Pieejams: https://lvportals.lv/wwwraksti/LVPORTALS/ VDKPARSKATS.PDF [skatīts 21.11.2019.].

Lešinskis, I. 1986. Kultūras sakari vai etniskā spiegošana: to kādreizējā veidotāja viedoklis. Latvija Šodien, Nr. 14, 1. dec., 109.-118. Ipp.

Metuzāle-Kangere, B. 1985. A derivational dictionary of Latvian = Latviešu valodas atvasinājumu vārdnīca . Hamburg: Buske.

Pasternaks, B. 1959. Doktors Živago. Kopenhāgena: Imanta.

Rūḳe-Draviṇa, V. 1986. Cilvēks un daba latviešu tautasdziesmās. Stokholma: Artilett.

Rūḳe-Draviṇa, V., Thars, J. 1985. Krišjān,na Barona Dainu parks. Stokholma: Artilett.

Sasse, S. 2017. "Words Are No Deeds": Trials against Literature in the Soviet Union. In: Grüttemeier, R. (ed.). Literary Trials: Exceptio Artis and Theories of Literature in Court. New York, London, Bloomsbury Academic.
Siliņš, U. 2015. Zem Dienvidu Krusta: kultūrvēsturiskas atmin,as. Pieejams: https://www.historia.lv/sites/default/ files/media/Biblioteka/Literatura/Gramatas/2015/ ZDK/zdk_kopsavilkums_060815.pdf [skatīts 21.11.2019.].

Strods, H. 2007. Trimdas izdevumu cenzūra Latvijas PSR 1958.-1989. gadā. No: Latvijas Vēsturnieku komisija, Latvijas Universitātes Latvijas Vēstures institūts. Latvijas kara muzejs. Latvija un Austrumeiropa 20. gadsimta 60.-80. gados: starptautiskās konferences referāti. 2006. gada 10. oktobris, Rïga = Latvia and Eastern Europe in the 1960s-1980s: Materials of international conference 10 October 2006, Riga. Rīga: Latvijas vēstures institūta apgāds, 88.-95. Ipp.

Strods, H. 2010. Ārzemju un trimdas literatūras cenzūra. No: Strods, H. PSRS politiskā cenzūra Latvijā 1940-1990. 1. dal̦a. Rīga: Jumava, 360.-400. Ipp.

Štrāle, A. 2005. Kā LPSR cenzūra gatavojās sadedzināt Bībeli: [par LPSR Ministru Padomes Galv. pārvaldes valsts noslēpumu aizsardzībai presē darbību]. Karogs, Nr. 8, 133.-138. Ipp.

Štrāle, A. 2005. Sešstūru zīmogs: no LPSR cenzūras sākotnes līdz funkciju izsīkumam. Daži aspekti. Diena, Nr. 182. Pieejams: http://news.Iv/Diena/2005/08/06/ sessturu-zimogs [skatīts 21.11.2019.].

Viška, J. 1973. V. Lāča Latvijas PSR Valsts bibliotēkas fondu komplektēšana (1945-1970). No: V. Lāča Latvijas PSR Valsts bibliotēka. Raksti $=$ Tpyды $=$ Proceedings $I V$, 146. Ipp.

Zīle, L. 1984. Latvijas Komunistiskajai partijai - 80. Rīga: Avots.

Zīle, L.. (red.) 1980. Latvijas KP CK Partijas vēstures institūts - PSKP CK Marksisma-l̦eninisma institūta filiāle = Институт истории партии при ЦК КП Латвии филиал Института марксизма-ленинизма при ЦК КПСС: 60. Rīga: Avots.

Великанова, Е. (сост.), Еремина, Л. (ред.) 1989. Цена метафоры, или Преступление и наказание Синявского и Даниэля. Москва: Книга.

Даниэль Юлий Маркович. В кн.: Скатов, Н. Н. (ред.) 2005. Русская литература ХХ века. Прозаики, поэты, драматурги: Биобиблиографический словарь: в 3 m. Москва: ОЛМА-ПРЕСС Инвест, с. 610-613. Pieejams: http://lib.pushkinskijdom.ru/LinkClick. aspx?fileticket=b0YDEQltxe0\%3d\&tabid=10547

Информационная справка Главлита в ЦК КПСС о содержание западной печати, освежающей 
положение советской интеллигенции, и о политике КПСС в области литературы и искусства 29.6.1971. В кн.: Горяева, Т. (сост.) 1997. История советской политической цензуры: документы и комментария. Москва: РОССПЕН, с. 582-584.

Камалова, Г. 2014. Исторические особенности правовой охраны служебной информации ограниченного доступа (служебной тайны) в советский период. Вестник Удмуртского университета. Серия "Экономика и право". Pieejams: https://cyberleninka.ru/ article/n/istoricheskie-osobennosti-pravovoy-ohrany-sluzhebnoy-informatsii-ogranichennogo-dostupa-sluzhebnoy-tayny-v-sovetskiy-period [skatīts 21.11.2019.].

Климонтович, Н. 2005. Из Мордовии в Сорбонну. Синявского прославила его литературоведение. NG Ex Libris, 38 (340). Pieejams: https://dlib.eastview. com [skatīts 21.11.2019.].

\section{NEPUBLICĒTI AVOTI}

LKP CK Partijas vēstures institūta bibliotēkas speciālās glabāšanas fonda vecākās metodiḳes $A$. Lucēvičas iesniegums direktorei L.. Zīlei par atbrīvošanu no darba 1990. gada 1. aprīīi. LVA, PA-200. f., 16. apr., 12. I., 15. Ip.

LPSR VB. Akts Nr. 1 25.03.1988 [par trimdas] grāmatu nodošanu Ārzemju literatūras komplektēšanas nodaḷai. LNB, Reto grāmatu un rokrakstu krājums, Latvijas Valsts bibliotēkas specfonda nodal̦a RXA 324, Nr. 35.

LU AB Misiṇa bibliotēka. LPSR ZA FB Literatūras speciālās glabāšanas nodaḷa. Dokumenti par specfondam nodotu literatūru.

LU AB Misina bibliotēka. LPSR ZA Literatūras speciālās glabāšanas nodaḷas lasītāju iesniegumi, 1985.-1990. gads.

Академия наук Латвийской ССР. Первому секретарю ЦК Компартии Латвии тов. Пуго Б. К. 13.05.1986. LVA, PA-101. f., 59. apr., 132. І., 13. Ip.

Главлит ЛССР. [Zin,ojums PSRS GLP sakarā ar LPSR GLP pārbaudi 1972. gada janv.] LVA, 917. f., 1.a apr., 113. I., 9. Ip.

Главлит ЛССР. Дополнение к инструкции “О порядке выписки, хранения и использования литературы капиталистических стран". LVA, 917.f., 1.a apr., 113. І., 3.-4. Ір.

Главлит ЛССР. Отчет по итогам контроля иностранной литературы за 1974 год. LVA, 917.f., 1.a apr., 128. І., 2. Ip.

Главлит ЛССР. Отчет по контролю бандеролей, отправляемых за границу и по контролю иностранной литературы, поступившей из-за границы на латышском языке за 1972 год. LVA, 917. f., 1.a apr., 113. І., 6. Ip.
Главлит ЛССР. Отчет по контролю бандеролей, поступивших из-за границы с иностранной литературой на латышском языке за 1986 год. LVA, 917. f., 1.a apr., 208. I., 37. Ip.

Главлит ЛССР. Порядок учета, хранения и использования иностранных изданий, отмеченных Главным управлениям двумя знаками “шестигранных" и пропускаемых в организации для особого использования. LVA, 917. f., 1.a apr., 113. І., 3. Ip.

Главлит ЛССР. Сводка о работе пункта при почтамте г. Риги за 1986 год. 6.01.1987. LVA, 917. f., 1.a apr., 208. І., 45. Ip.

Главлит ЛССР. Сводка о работе пункта при почтамте г. Риги за 1987 год. 14.01.1988. LVA, 917. f., 1.a apr., 212. I., 36. Ip.

Главлит СССР. Секретарю ЦК Компартии Латвии тов. Калнберзину Я. Я. 31.07.1958. LVA, PA-101. f., 21. apr., 77. І., 11.-12. Ip.

Главлит СССР. Секретарю ЦК Компартии Латвии тов. Калнберзину Я. Я. 19.08.1958. LVA, PA-101. f., 21. apr., 77. I., 14. Ip.

Главлит ЛССР. Секретарю ЦК КПЛ Горбунову А. В. и заместителю председателя Совета Министров ЛССР тов. Барткевичу Л. Л. О контроле эмигрантской литературы, поступавшей в республике по открытым почтовым каналам 2.02.1987. LVA, 917. f., 1.a apr., 210. I., 7. Ip.

Главлит ЛССР. Секретарю ЦК КПЛ т. Дризул А. А. 12.07.1972. LVA, 917. f., 1.a apr., 115. І., 24. Ip.

Главлит ЛССР. Справка о работе цензорского пункта Главлита Латвийской ССР при почтамте гор. Риги за 1958 год. LVA, PA-101. f., 22. apr., 83. І., 6.-8. Ip. 
ИИП ЦК КПЛ. Мероприятия по устранению недостатков, отмеченных при проверке работы Института истории партии при ЦК КП Латвии комиссией ИМЛ при ЦК КПСС. LVA, РА-200. f., 11. apr., 4. І., 60. Ір.

ИИП ЦК КПЛ. О работе ИИР ЦК КП Латвии - филиала ИМЛ при ЦК КПСС. 30.01.1985. LVA, РА-200. f., 11. apr., 39. І., 17. Ip.

ИИП ЦК КПЛ. Отчет ИИП ЦК КПЛ - филиала Института марксизма-ленинизма при ЦК КПСС о научно-исследовательской деятельности за 1980 год. LVA, РА-200. f., 8. арr., 4. І., 27. Ір.

ИИП ЦК КПЛ. Отчет ИИП ЦК КПЛ - филиала Института марксизма-ленинизма при ЦК КПСС о научно-исследовательской деятельности за 1981 год. LVA, РА-200. f., 8. apr., 17. І., 47. Ip.

ИИП ЦК КПЛ. Отчет о научно-исследовательской деятельности за 1978 год. LVA, PA-200. f., 7. apr., 3. I., 28. Ip.

ИИП ЦК КПЛ. Отчет о работе и списки сотрудников, 1964 год. LVA, РА-200. f., 1. apr., 249. І., 40. Ip.

ИИП ЦК КПЛ. Приказ директора Института № 17 3.03.1986. LVA, РA-200. f., 13. apr., 24. I., 17. Ip. ИИП ЦК КПЛ. Приказ директора Института № 63 20.11.1986. LVA, PA-200. f., 13. apr., 24. I., 68. Ip.
ИИП ЦК КПЛ. Протокол заседания дирекции № 8. 31.10.1984. LVA, РА-200. f., 11. арr., 4. І., 47. Ір. ИИП ЦК КПЛ. Управлению делами ЦК Компартии Латвии. 16.08.1985. LVA, PA-200. f., 11. apr., 39. І., 62. Ip.

ИИП ЦК КПЛ. Характеристика А. А. Луцевич. 26.01.1987. LVA, PA-200. f., 16. apr., 12. І., 13. Ip.

ИИП ЦК КПЛ. Центральному Комитету Компартии Латвии. 2.7.1985. LVA, PA-200. f., 11. apr., 39. І., 54. Ip.

Отдел спецфонда Гос. библиотеки Латвийской СССР. Секретно. Инвентарная книга для журналов. 1948.-1972. g. LNB, Reto grāmatu un rokrakstu krājums, VB specfonda nodaḷa RXA 324, Nr. 17.

Отчет о работе Главлита ЛССР за 1987 год. LVA, 917.f., 1.a apr., 212. I., 8. Ip.

Председатель комитета государственной безопасности ЛССР Я. Веверис секретарю ЦК КПЛ А. Воссу о хранении латышской эмигрантской литературы 5.07.1960. LVA, PA-101. f., 23. apr., 136. I., 135. Ip.

ЦК Компартии Латвии. Об оказание помощи в создание и дальнейшем развитие специального хранения Института истории партии при ЦК Компартии Латвии. 19.06.1986. LVA, РA-101. f., 59. apr., 132. І., 15. Ip. 